\title{
Comparative Analysis of Senior Secondary School Students' Performance with School-Based Assessment Scores of Continuous Assessment and Promotion Examination in Delta State
}

\author{
Patrick U. Osadebe $e^{1, *}$ \\ ${ }^{1}$ Department of Guidance and Counselling, Delta State University, Abraka, USA \\ *Correspondence: Department of Guidance and Counselling, Delta State University, Abraka, \\ USA. E-mail: drosadebeuzo@gmail.com
}

Received: October 29, 2014 Accepted: February 5, 2015 Published: February 17, 2015

doi:10.5296/ije.v7i1.7112 URL: http://dx.doi.org/10.5296/ije.v7i1.7112

\begin{abstract}
The study was carried out to comparatively analyze the school-based assessment scores of continuous assessment and promotion examination of students from SSII to SSIII, conducted by the state ministry of Education. This helped to determine students' performance in each assessment type respectively. This was to correct the addition of continuous assessment and examination scores to obtain a single score as performance for each student. It is either Continuous Assessment or Examination to determine the students' performance using English Language and Mathematics. Four research questions and four hypotheses were drawn to guide the study. A sample of 100 students was randomly drawn for the study. The continuous assessment and promotion examination results in schools for senior secondary two (SS II) students in 2011/2012, and 2012/2013 were used for analyses. The instruments used for continuous assessment and promotion examination were valid and reliable. The continuous assessing score was based on 30 marks while promotion examination on 70 marks. The marks were converted equivalently. Mean was used to answer the research question while t-test was used to test each hypothesis at .05 level of significance. The result showed that students performed better in continuous assessment for English Language and Mathematics in the two academic sessions used. It was noted that continuous assessment should be used as the only school- based assessment for students in schools.
\end{abstract}

Keywords: School-Based Assessment, Continuous Assessment and Promotion Examination 


\section{Introduction}

Assessment that takes place in the school is called school-based assessment. The school-based assessment currently in the secondary schools in Delta state of Nigeria is made up of continuous assessment and promotion examination. The Delta State Ministry of Education in its attempt to ensure comparability of standard in schools, prepares items or questions for promotion examination from one class to the other. The teachers also prepared and help to conduct the examination which comes at the end of a session. The teachers conducted continuous Assessment (CA) in schools. The score of continuous assessment (CA) is usually added to the score of promotion examination to determine each students performance in a subject. The study determined students performance in the promotion examination from senior secondary Two (SSII) to Senior Secondary Three (SSIII) for 2011/2012 and 2012/2013 academic sessions. It has been pointed out that school-based assessment involves the use of valid and reliable test, observation, questionnaire, interview and other techniques to obtain information about students behaviour upon which judgment is made. (Osadebe, 2013). This implies that for every assessment there should be judgment on the performance of students. The main focus of assessment is to analyze information provided by tests, interview, and observation and to combine the information to make complex and important judgment about individual (Murphy \& Davidshofer 1988, Osadebe, 2013). There are two types of assessment being practice in senior secondary schools. These include continuous assessment and single assessment usually called examination.

One of the main focuses of the National Policy on Education was the emphasis on Continuous Assessment. Thus, the Federal Government of Nigeria (FGN) in 1979 declared continuous assessment in schools in the National Policy on Education. It was maintained that Continuous Assessment (C.A) should be used at all levels of Education in Nigeria (FGN, 1981, 1998 \& 2004). Government pointed out that CA would achieve the following:

a. give the teacher greater involvement in the overall assessment of his or her pupils,

b. provide a more valid assessment of the child's overall ability and performance,

c. enable teachers to be more flexible and innovative in their instruction,

d. provide a basis for more effective guidance of the child,

e. provide a basis for the teacher to improve his or her instructional methods, and

f. reduce examination malpractices. (Federal Ministry of Education, Science and Technology, 1985, p.5).

Continuous assessment was introduced because of the problems associated with single assessment called examination. The single assessment only focuses on the cognitive behaviour of students. The use of examination to determine students' performance was just an interim measure that should have given way to continuous assessment. Its long use was not government intension. It was therefore a problem. Continuous assessment on the other side focuses on the cognitive, affective and psychomotor behaviour of students. Hence, continuous assessment was preferred because it is comprehensively. CA measures all the 
domains of behaviour. The use of examination was considered a temporary measure until continuous assessment was fully implemented. The CA takes into account of the learners' performance throughout the period of schooling. It is valid and reliable in determining students' performance. Therefore, it is necessary to determine students' performance in CA independently than combining it with examination scores.

Teachers practice continuous assessment but are not given the opportunity to interpret their scores independent of examination score. Instead they add CA score to examination score to obtain the overall score of each student. It should be noted that 34years ago (1979-2014) after the Federal Government of Nigeria had emphasized the need of continuous assessment in secondary schools, it has not been fully implemented. A student overall performance is made up of continuous assessment and examination scores. The performance of students in continuous assessment and examination has not been addressed respectively (Osadebe, 2014). This is because continuous assessment score is added to examination score to obtain the overall performance for each student. This is a major problem in the school base assessment. Moreover, examination (single assessment) which government criticized because it focuses on the cognitive behaviour of students was weighted higher than the continuous assessment that was considered better and comprehensive (cognitive, affective and psychomotor). Continuous assessment is based on 30 marks while examination is 70 in senior secondary schools in Delta State.

However, the problems associated with assessment-type in terms of student performance could be determined through comparative analysis. This will help to find out where students performed better. The first step of determining students' performance respectively is to convert the score of continuous assessment and examination to percentage respectively. This will help to compare the performance of students in continuous assessment and examination. The mode of assessment where students performed better could be determined. It is either continuous assessment or examination.

The study considered English Language and Mathematics. These are core subjects that must be passed at credit level by the secondary school students to be able to enter the university and other tertiary institutions (Osadebe, 2003, National University Commission, 2011). A student who passed English Language and Mathematics at credit level will have more advantage than one who did not pass at credit level. Analysis of the performance of students in English Language and Mathematics is very essential. The session of 2011/2012 and $2012 / 2013$ are very current and would give a better result. The conversion to equivalent score was necessary to describe performance.

\section{Literature Review}

Continuous Assessment (CA) in schools is the process of obtaining information about a student behaviour in the areas of cognitive, affective and psychomotor upon which decisionnis made (Federal Ministry of Education, Science and Technology, 1985; Osadebe, 2013). The information is obtained through the use of test, questionnaire, observation 
interview among others. Continuous assessment implies that for every time a teacher teaches the student, there information should be obtained about each student for scoring and recording. Therefore, at the end of the educational programme, a student performance could be described from the first assessment to the last assessment in the school (Osadebe, 2013). This provides a cumulative and a comprehensive picture about the student performance. On the other side, promotion examination is the process of obtaining information about a student cognitive behaviour only at the end of a course or programme. It requires mainly the use of test. It is often called summative evaluation (Gronlund, 1995).

Individual behaviour varies and has long been classified for easy assessment (Osadebe, 2013). The classifications were earlier identified by the following scholars: Cognitive (Bloom, 1956), Affective (Krathwohl, 1964) and psychomotor (Harrow, 1972). Continuous assessment focuses on the three domains of behaviour which include cognitive, affective and psychomotor. Examination on the other side focuses on the cognitive. Therefore CA is more comprehensive because it contains all the behaviour domains. CA is also systematic, cumulative and guidance oriented.

Continuous assessment and promotion examination could be used to describe students' behaviour or performance respectively. This is possible when they are based on equivalent mark (such as 100) respectively. However, the study focuses on which assessment type is better.

The use of equivalent score was pointed out by the Federal Ministry of Education, Science and Technology, (1985) and Osadebe, (2013). There are related studies based on school based assessment but with different dimensions. These include Omole (2007), and Osadebe (2014). These studies mentioned are good but did not separate continuous assessment score from examination score before use.

The study is based on the Theory of Measurement. The theory maintains that scores for students' performance should be averaged. When two scores are added together, the mean would be the best measure to describe performance. Mean is the best measure of central tendency which helps to determine students' performance (Osadebe, 2014). With the use of the normal curve, students' scores could be transformed or compared with z-score, t-score and stanine as in Aiken (1979), Gronlund (1985), Ukwuije and Orluwene (2012), Osadebe (2013). Therefore, the addition of C.A. and examination score to describe performance negates the Theory of Measurement. Christensen, (2014) criticized the addition of C.A. and examination scores to describe performance and supported the use of only C.A. to assess the student's performance. This was what the study supported. The study separated C.A. score from examination score before the comparative analysis. This is a gap the study covered.

In 1979, the Federal Government of Nigeria as a follow up of the National Curriculum Conference of 1969 declared the implementation of C.A. in schools. At the time of implementation, teachers needed to be trained. Then, as an interim measure, continuous assessment (C.A) score and examination score were to be used to determine students' performance. Surprisingly, after 34 years of the declaration of the use of C.A. in schools, it is still not being implemented independently. Continuous assessment score is based on 30 
marks which is added to examination of 70 marks to obtain the overall performance for each student. This has often made it difficult to report the performance of students in C.A. and promotion examination respectively. Therefore, the problem of the study is: what is the performance of students in continuous assessment and the promotion examination in schoolbased assessment respectively?

The following questions guided the study

(1) What is the performance of students in English Language on continuous assessment and promotion examination for 2011/2012 session of school-based assessment?

(2) What is the performance of students in Mathematics on continuous assessment and promotion examination for 2011/2012 session of school-based assessment?

(3) What is the performance of students in English Language on continuous assessment and promotion examination for 2012/20 13 session of school-based assessment?

(4) What is the promotion performance of students in Mathematics on continuous assessment and examination for 2012/2013 session of school-based assessment?

The following null hypotheses were tested

1. There is no significant difference between students' performance in English Language on continuous assessment and promotion examination for 2011/2012 session of school-based assessment.

2. There is no significant difference between students' performance in Mathematics on continuous assessment and promotion examination for 2011/2012 session of school-based assessment.

3. There is no significant difference between students' performance in English Language on continuous assessment and promotion examination for 2012/20 13 session of school-based assessment.

4. There is no significant difference between students' performance in Mathematics on continuous assessment and promotion examination for 2012/20 13 session of school-based assessment.

\section{Method}

The study is comparative. It was comparative analysis of continuous assessment and promotion examination scores to determine students' performance respectively. Thus each assessment-type determined students' performance in English Language and Mathematics for 2011/2012 and 2012/2013 respectively. The dependent variable of the study is performance. The main independent variable is assessment-type (continuous assessment and promotion examination). Thus the performance of students depends on continuous assessment and promotion examination scores. 


\section{$\triangle 1$ Macrothink}

International Journal of Education

ISSN 1948-5476

2015, Vol. 7, No. 1

The population of the study comprises all senior secondary two (SSII) students in Ukwuani Local Government Area of Delta State where the study was carried out. A sample of 100 SSII students was randomly selected through simple random sampling of balloting and stratified random sampling techniques.

The continuous assessment and promotion examination scores of students were obtained from the schools' academic record. The researcher did not administer any instrument because the data required were in the school academic record. Teachers administered continuous assessment with their instruments. The promotion examination was conducted by experts in Ministry of Education as promotion examination from SSII to SSIII. The instruments used were assumed to be valid and reliable. It was possible to determine students' performance in each assessment-type.

The maximum mark for continuous assessment in Delta State is 30 while examination is 70 . Then, the addition of both marks $(30+70)$ is 100 . Therefore, the addition of CA and examination scores usually determines each student's performance. This is a wrong approach because each assessment type is expected to be independent. The researcher in attempt to correct this, then converted each assessment- type mark to 100. That is whatever, a student obtained in C.A was based on 100 marks to describe performance. The same applied to promotion examination. These were required for comparative analysis of the study. It was noted that mean was more appropriate in describing students' performance. Therefore, mean was used to answer the research questions while z-test was used to test each hypothesis at .05 level of significance.

\section{Results and Discussion}

Research question and corresponding hypothesis were determined in one table.

Research Question one: What is the performance of students in English Language on continuous assessment and promotion examination for 2011/2012 session of school-based assessment?

Hypothesis one: There is no significant difference between students' performance in English Language on continuous assessment and promotion examination for 201 1/2012 session of school-based assessment.

Table 1. Mean and Z-test Analysis of SSII Students' Performance in English Language on Continuous Assessment and Promotion Examination for 2011/2012 Session School-based Assessment

\begin{tabular}{lcccccc}
\hline \multicolumn{1}{c}{ Assessment type } & $\mathbf{N}$ & $\overline{\mathbf{x}}$ & SD & $\begin{array}{c}\text { Calculated } \\
\text { Z-value }\end{array}$ & $\begin{array}{c}\text { Critical } \\
\text { Z-value }\end{array}$ & Decision \\
\hline $\begin{array}{l}\text { Continuous assessment } \\
\text { Promotion Examination }\end{array}$ & 100 & 60.50 & 3.00 & 9.8 & 1.96 & $\begin{array}{c}\text { Reject } \\
\text { (significant) }\end{array}$ \\
\hline
\end{tabular}

$\mathrm{P}<.05$ 


\section{Al Macrothink}

International Journal of Education

ISSN 1948-5476

2015, Vol. 7, No. 1

Table 1 showed that the mean score of students in continuous assessment of 65.10 was higher than that of promotion examination of 60.50. The result implies that students' performance in English Language was better in continuous assessment than promotion examination for 2011/2012 academic session

The table 1 also showed that the calculated Z-value of 9.8 was greater than the critical Z-value of 1.96 at .05 level of significance. The null hypothesis was therefore rejected. This implies that there was significant difference between the students' performance in English Language on continuous assessment and promotion examination for 2011/2012 academic session. Students' performance in continuous assessment was higher than promotion examination.

Research question Two: What is the performance of students in Mathematics on continuous assessment and promotion examination for 2011/2012 session of school-based assessment?

Hypothesis Two: There is no significant difference between students' performance in Mathematics on continuous assessment and promotion examination for 2011/2012 session of school-based assessment.

Table 2. Mean and Z-test Analysis of SSII Students' Performance in Mathematics on Continuous Assessment and Promotion Examination for 2011/2012 Session School-based Assessment

\begin{tabular}{lcccccc}
\hline \multicolumn{1}{c}{ Assessment type } & $\mathbf{N}$ & $\overline{\mathbf{x}}$ & SD & $\begin{array}{c}\text { Calculated } \\
\text { Z-value }\end{array}$ & $\begin{array}{c}\text { Critical } \\
\text { Z-value }\end{array}$ & Decision \\
\hline $\begin{array}{l}\text { Continuous assessment } \\
\text { Promotion Examination }\end{array}$ & 100 & 58.20 & 6.50 & 4.02 & 1.96 & $\begin{array}{c}\text { Reject } \\
\text { (significant) }\end{array}$ \\
\hline $\mathrm{P}<.05$ & & & & & &
\end{tabular}

Table 2 showed that the mean score of students in continuous assessment of 62.30 was higher than that of promotion examination of 58.20. The table 2 also showed that the calculated $\mathrm{Z}$-value of 4.02 was greater than the critical $\mathrm{Z}$ value of 1.96 at .05 level of significance. The null hypothesis was therefore rejected. This implies that there was significant difference between the students' performance in Mathematics on continuous assessment and promotion examination for 2011/2012 academic session. Students' performance in continuous assessment was higher than promotion examination.

Research question Three: What is the performance of students in English Language on continuous assessment and promotion examination for 2012/2013 session of school-based assessment?

Hypothesis Three: There is no significant difference between students' performance in English Language on continuous assessment and promotion examination for 2012/2013 session of school-based assessment. 
Table 3. Mean and Z-test Analysis of SSII Students' Performance in English Language on Continuous Assessment and Promotion Examination for 2012/2013 Session School-based Assessment

\begin{tabular}{|c|c|c|c|c|c|c|}
\hline Assessment type & $\mathbf{N}$ & $\overline{\mathbf{x}}$ & SD & $\begin{array}{c}\text { Calculated } \\
\text { Z-value }\end{array}$ & $\begin{array}{l}\text { Critical } \\
\text { Z-value }\end{array}$ & Decision \\
\hline Continuous assessment & & 67.30 & 11.30 & & & Reject \\
\hline Promotion Examination & 100 & 62.20 & 9.20 & 3.49 & 1.96 & (significant) \\
\hline
\end{tabular}

The table 3 showed that the mean score of students in continuous assessment of 67.30 was higher than that of promotion examination of 62.20. The result implies that students' performance in English Language was better in continuous assessment than promotion examination for 2012/2013 academic session.

The table also showed that the calculated Z-value of 3.49 was greater than the critical Z-value of 1.96 at 0.05 level of significance. The null hypothesis was therefore rejected. This implies that there was significant difference between the students' performance in English Language on continuous assessment and promotion examination for 2012/2013 academic session. Students' performance in continuous assessment was higher than promotion examination.

Research question Four: What is the performance of students in Mathematics on continuous assessment and promotion examination for 2012/2013 session of school-based assessment?

Hypothesis Four: There is no significant difference between students' performance in Mathematics on continuous assessment and promotion examination for 2012/2013 session of school-based assessment.

Table 4. Mean and Z-test Analysis of SSII Students' Performance in Mathematics on Continuous Assessment and Promotion Examination for 2012/2013 Session School-based Assessment

\begin{tabular}{lcccccc}
\hline \multicolumn{1}{c}{ Assessment type } & $\mathbf{N}$ & $\overline{\mathbf{x}}$ & SD & $\begin{array}{c}\text { Calculated } \\
\text { Z-value }\end{array}$ & $\begin{array}{c}\text { Critical } \\
\text { Z-value }\end{array}$ & Decision \\
\hline $\begin{array}{l}\text { Continuous assessment } \\
\text { Promotion Examination }\end{array}$ & 100 & 64.18 & 12.51 & & & Reject \\
\hline
\end{tabular}

$\mathrm{P}<.05$

Table showed that the mean score of students in continuous assessment of 64.18 was higher than that of examination of 60.13. The result implies that students' performance in Mathematics was better in continuous assessment than promotion examination for 2012/2013 academic session.

The table 4 also showed that the calculated $Z$-value was greater than the critical $Z$ value at 0.05 level of significance. The null hypothesis was therefore rejected. This implies that there was significant difference between the students' performance in Mathematics on continuous 
assessment and promotion examination for 2012/2013 academic session. Students' performance in continuous assessment was higher than promotion examination.

The result of the study shows that students' performance was higher in continuous assessment than promotion examination when determined with equivalent scores using percentage and mean. This is against the addition of 30 marks for CA to 70 marks of examination to determine students' performance. The comparative analysis of continuous assessment and promotion examination on equivalent score, and the use of mean revealed that continuous assessment could be used to determine students' performance throughout their schooling years. The result is in line with Osadebe (2013), Christenson (2014), and Osadebe (2014) who supported that continuous assessment should be used to assess students' performance in their various subjects. The result contradicted Federal Government of Nigeria (20O4) that continuous assessment and examination should be used to enhance students' performance. Government should note that the result of the study has revealed that continuous assessment could only be used to determine students' performance in the various subjects in schools.

The study found significant difference on the performance of students' in both English language and Mathematics on continuous assessment and promotion examination for $2011 / 2012$ and 2012/2013 respectively. The result is similar to the work of Omole (2007) whose study compared students' performance in English language and Mathematics but did not separate continuous assessment scores from examination scores. The result was also similar to the findings of Osadebe (2013).

\section{Conclusion}

The study was carried out to comparatively analyze the school-based assessment scores of continuous assessment and promotion examination. The study was carried out on senior secondary school students in Delta State. The result of the study revealed that students performed better in Continuous Assessment (CA) than promotion examination. Therefore Continuous Assessment (CA) should always be used to assess students' performance in schools.

\section{Acknowledgement}

The author is grateful to his wife, Mrs. J. F. Osadebe for her contribution to the publication of this paper.

\section{References}

Aiken, L.W. (1979). Psychological testing and assessment. Boston: Allyn and Bacon, Inc.

Bloom, B.S. (1956). Taxonomy of Educational Objectives Cognitive Domain. New York. 
Christensen, C. (2014). Ways continuous assessment can help students learn. Retrieve $1^{\text {st }}$ February, 2014, from http:/gettingsmart.com/6ways'continuous assessment.

Federal Government of Nigeria (1981). National policy on education. Lagos: Government Printing Press.

Federal Government of Nigeria (1998). National policy on education. Lagos: Government Printing Press.

Federal Government of Nigeria (2004). National policy on education, (4th Ed). Lagos. Nigeria Educational Research and Development Council press.

Federal Ministry of Education, Science \& Technology. (1985). A Handbook on continuous assessment. Lagos: Heinemann Educational Books (Nig) Ltd.

Gronlund, N.E. (1985). Measurement and Evaluation in Teaching (5th Ed.). New York: Macmillan Publishing Co., Inc.

Harrow, A.J.A. (1972). Taxonomy of the psychomotor domain. New York: David McKay Co., Inc.

Krathwohl, D.R. (1964). Taxonomy of Affective Domain. New York: David McKay Co. Inc.

Murphy, K.R., \& Daviddshofer, C.O. (1988). Psychological testing. New Jersey: Prentice Hall International Inc.

National University Commission (2011). Benchmark minimum academic standards for postgraduate programmes in education in Nigerian universities. Abuja: National University Commission.

Omole, D.O.K. (2007). Comparative study of students' performance in school-based assessment and certificate examination at the upper basic education level in FCT. Nigerian Journal of Educational Research and Evaluation, 7(1), 50-56.

Osadebe, P.U. (2013). Assessment of students' perception on population control measures. British Journal of Advance Academic Research, 2(1), 95-1 03.

Osadebe, P.U. (2013). Teachers' assessment of learning classroom learning outcomes. Journal of Education and Practice, 5(15), 15-21.

Osadebe, P.U. (2014). Assessment score of university lecturers. Journal of Education and Practice, 5(2), 8-14.

Osadebe, P.U. (2014). Standardization of Economics Achievement Test for assessment and comparing of students' measurement. International Education Studies, 7(5), 94-103. http://dx.doi.org/10.5539/ies.v7n5p94

Osadebe. P.U. (2014). Assessment of Gender Participation in Economic Development. Journal of Education and Practice, 5(9), 140-144.

Ukwuije, R.P.I., \& Orluwene, G.W. (2012). Peanut Educational statistics. Port Harcourt: 
Chadik Printing Press. 2015, Vol. 7, No. 1

\section{Copyright Disclaimer}

Copyright for this article is retained by the author(s), with first publication rights granted to the journal.

This is an open-access article distributed under the terms and conditions of the Creative Commons Attribution license (http://creativecommons.org/licenses/by/3.0/). 